\title{
Antimicrobial activities of the methanol extract, fractions and compounds from Ficus polita Vahl. (Moraceae)
}

\author{
Victor Kuete ${ }^{1 *}$, Justin Kamga ${ }^{2}$, Louis P Sandjo ${ }^{2}$, Bathelemy Ngameni $^{3}$, Herve MP Poumale ${ }^{2}$, \\ Pantaleon Ambassa ${ }^{2}$, Bonaventure T Ngadjui ${ }^{2,3}$
}

\begin{abstract}
Background: Many plants of the family Moraceae are used in the treatment of infectious diseases. Ficus polita Vahl., an edible plant belonging to this family is used traditionally in case of dyspepsia, infectious diseases, abdominal pains and diarrhea. The present work was designed to assess the antimicrobial activity of the methanol extract from the roots of F. polita (FPR), as well as that of its fractions (FPR1-5) and two of the eight isolated compounds, namely euphol-3-O-cinnamate (1) and (E)-3,5,4'-trihydroxy-stilbene-3,5-O- $\beta$-D-diglucopyranoside (8).
\end{abstract}

Methods: The liquid microdilution assay was used in the determination of the minimal inhibitory concentration (MIC) and the minimal microbicidal concentration (MMC), against seven bacterial and one fungal species.

Results: The results of the MIC determination showed that the crude extract, fractions FPR1, FPR2 and compound $\mathbf{8}$ were able to prevent the growth of the eight tested microorganisms. Other samples showed selective activity. The lowest MIC value of $64 \mathrm{\mu g} / \mathrm{ml}$ for the crude extract was recorded on $50 \%$ of the studied microbial species. The corresponding value for fractions of $32 \mu \mathrm{g} / \mathrm{ml}$ was obtained on Salmonella typhi, Escherichia coli and Candida albicans ATCC strains. The MIC values recorded with compound $\mathbf{8}$ on the resistant Pseudomonas aeruginosa PA01 strain was equal to that of chloramphenicol used as reference antibiotic.

Conclusion: The obtained results highlighted the interesting antimicrobial potency of $F$. polita as well as that of compound $\mathbf{8}$, and provided scientific basis for the traditional use of this taxon in the treatment of microbial infections.

\section{Background}

According to the World Health Organization (WHO), infectious diseases is the first cause of death worldwide with more that $50 \%$ of the death appearing in tropical countries. In the developing countries, treatment of such diseases is complicated not only because of the occurrence of resistant microorganisms to the commonly used antibiotics, but also because of the low income of the population, which drastically reduce their accessibilities to appropriate drugs. It is reported that about $80 \%$ of the world population is dependent (wholly or partially) on plant-based drugs [1]. Scientific experiments on the

\footnotetext{
* Correspondence: kuetevictor@yahoo.fr

'Department of Biochemistry, Faculty of Science, University of Dschang, Cameroon

Full list of author information is available at the end of the article
}

antimicrobial properties of plant components were first documented in the late $19^{\text {th }}$ century [2]. Naturally occurring antimicrobials can be derived from plants, animal tissues, or microorganisms [3]. The shortcomings of the drugs available today propel the discovery of new pharmacotherapeutic agents in herbal medicine [4]. Amongst the medicinal plants investigated in our research team, the family Moraceae is largely represented. Some of the plants of the genus Ficus, Morus, Treculia, Dorstenia, also belonging to this family, were previously reported for their antimicrobial activities [5-11]. In our continuous search on medicinal plants of the family Moraceae, we focused herein on Ficus polita Vahl. F. polita is an edible plant growing in lowland rainforest and gallery forest (West and Central Africa), coastal and dry forest (East and Southern Africa), up to an altitude of $1200 \mathrm{~m}$. The
C Biomed Central

() 2011 Kuete et al; licensee BioMed Central Ltd. This is an Open Access article distributed under the terms of the Creative Commons Attribution License (http://creativecommons.org/licenses/by/2.0), which permits unrestricted use, distribution, and reproduction in any medium, provided the original work is properly cited. 
edible fruits are chewed for dyspepsia, while leaves (also edible) or bark and roots infusions are used in the treatment of infectious diseases, abdominal pains and diarrhea $[12,13]$. The phytochemical investigation of this taxon [14] revealed the presence of a cerebroside named politamide, sitosterol 3-O- $\beta$-D-glucopyranoside, betulinic acid, stigmasterol and lupeol. The methanol and dichloromethane extract from the stem exhibited anti-inflammatory activities [15]. Water extract from this plant also showed anti-HIV activity through the inhibition of HIV-1 reverse transcriptase activity [16]. Extracts from the leaves of $F$. polita also exhibited antimalarial action against Plasmodium falciparum cultured in vitro [17]. The present work was therefore undertook to evaluate the antimicrobial activities of the extract, fractions and compounds from the roots of this plants, and to identify some of it's active components.

\section{Methods}

\section{Plant material}

The roots of Ficus polita Vahl., were collected in Yaounde, Center region of Cameroon in May 2007. The plant was identified at the National Herbarium (Yaounde, Cameroon) where a voucher specimen was deposited under the reference number 39955/HNC.

\section{Extraction and purification}

The air-dried and powdered root $(3.1 \mathrm{~kg})$ was soaked in $10 \mathrm{~L}$ of methanol for $48 \mathrm{~h}$, at room temperature. The methanol extract was concentrated under reduced pressure to give $216 \mathrm{~g}$ of a brown residue that constituted the crude extract (FPR). Part of FPR (200 g) was submitted to silica gel $60(0.04-0.063 \mathrm{~mm}, 200 \mathrm{~g})$ vacuum flash chromatography using as eluent, hexane (Hex), hexane-ethyl acetate (Hex-EtOAc) mixture of increasing polarity, and methanol $(\mathrm{MeOH})$. This was conducted in accordance to the previously reported procedure [14]. Five fractions were obtained, FPR1 (from Hex, 23 g), FPR2 (Hex-EtOAc 75\%; 18 g), FPR3 (Hex-EtOAc 50\%, $14 \mathrm{~g})$, FPR4 (EtOAc, $12 \mathrm{~g})$ and FPR5 $(\mathrm{MeOH}, 19 \mathrm{~g})$. A part from FPR3, other fractions, upon antimicrobial assay were subjected to further purification. FPR1 (20 g) was column chromatographed using silica gel 60 (65 g) and Hex-EtOAc gradient as eluent. One hundred and forty seven (147) fractions of $50 \mathrm{ml}$ each were collected. Sub-fractions 2-7 obtained with Hex-EtOAc 2.5\% and combined on the basis of TLC analysis afforded compound 1 [18]. Sub-fraction 34-40 (Hex-EtOAc 10\%) yielded compound 2 [19]. Sub-fractions 51-57 (Hex-EtOAc 15\%) yielded compound 3 [20], while subfractions $76-81$ obtained in Hex-EtOAc $22.5 \%$ gave compound 4 [21]. FPR2 was subjected to column chromatography (CC) similarly to FPR 1 and 76 fractions of $50 \mathrm{ml}$ each were collected. Sub-fractions 26-33 eluted with Hex-EtEtOAc 15\% yielded compound 5 [22] while sub-fractions 38-41 eluted with Hex-EtEtOAc 20\% afforded compound 6 [23]. FPR4 was subjected to CC similarly to FPR1 and 2 using $\mathrm{CH}_{2} \mathrm{Cl}_{2}-\mathrm{MeOH}$ gradient as eluent and 107 sub-fractions were collected. Subfractions obtained in $\mathrm{CH}_{2} \mathrm{Cl}_{2}-\mathrm{MeOH} 5 \%$ afforded compound 7 [22]. FPR5 was also subjected to CC similarly to FPR4 and 93 sub-fractions were collected. Sub-fractions obtained in $\mathrm{CH}_{2} \mathrm{Cl}_{2}-\mathrm{MeOH} 10 \%$ afforded compound 8 [22]. The chemical structures of the isolated compounds are illustrated in Figure 1.

\section{General procedure for the identification and characterization of isolated compounds}

Aluminum sheet pre-coated with silica gel $60 F 254 \mathrm{~nm}$ (Merck) was used for thin layer chromatography; The spots were visualized using both ultraviolet light (254 and $366 \mathrm{~nm}$ ) and $50 \% \mathrm{H}_{2} \mathrm{SO}_{4}$ spray reagent. NMR spectra were recorded on a Bruker Avance 300 at $300 \mathrm{MHz}$ $(1 \mathrm{H})$ and $75 \mathrm{MHz}$ and Bruker Avance 600 at $600 \mathrm{MHz}$ $\left({ }^{1} \mathrm{H}\right)$ and $150 \mathrm{MHz}\left({ }^{13} \mathrm{C}\right)$, with the residual solvent peaks as internal references. The melting point (m.p.) were determined using a Kofler microhot stage apparatus. Mass spectra were recorded with API QSTAR pulsar mass spectrometer. The structures of the compounds were confirmed by comparing with reference data from available literature.

\section{Antimicrobial assays}

\section{Microbial strains and culture media}

The studied microorganisms included reference strains of Providencia smartii (ATCC29916), Pseudomonas

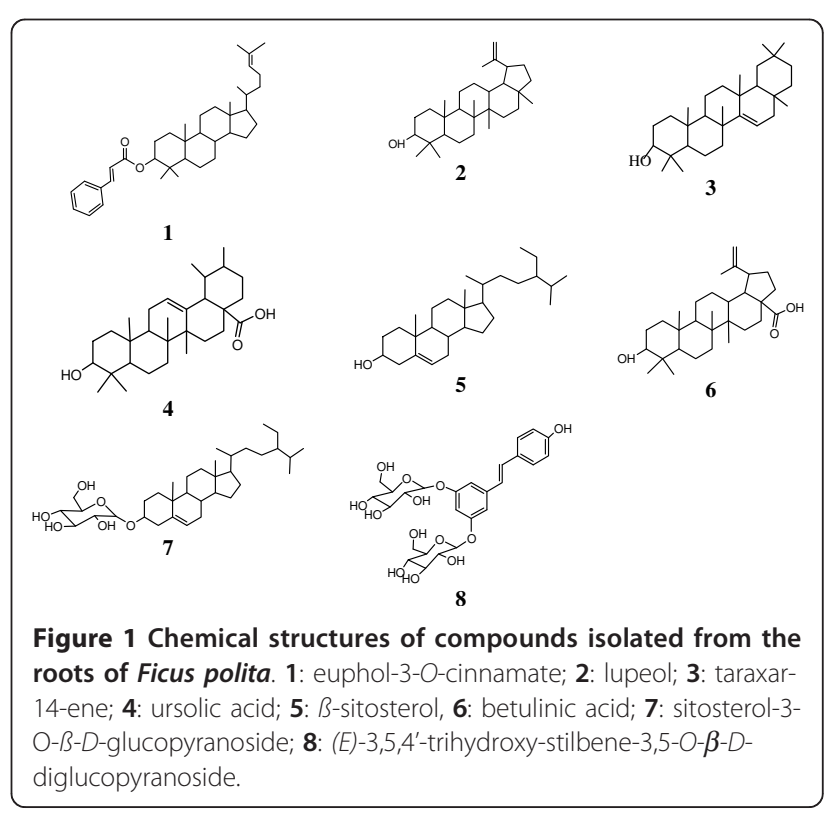


aeruginosa (PA01), Klebsiella pneumoniae (ATCC 11296), Staphylococcus aureus (ATCC25922), Salmonella typhi (ATCC6539), Escherichia coli (ATCC8739 and AG100), Candida albicans (ATCC 9002) obtained from the American Type Culture Collection. They were maintained on agar slant at $4{ }^{\circ} \mathrm{C}$ and sub-cultured on a fresh appropriate agar plates $24 \mathrm{~h}$ prior to any antimicrobial test. Nutrient Agar and Sabouraud Glucose Agar were used for the activation of bacteria and fungi respectively. The Mueller Hinton Broth (MHB) was used for the MIC and MMC determinations. The Mueller Hinton Agar (MHA) was also used for the determination of the MMC on these species.

\section{Chemicals for antimicrobial assay}

Chloramphenicol (Sigma-Aldrich, St. Quentin Fallavier, France) and Nystatin (Sigma-Aldrich) were used as reference antibiotics (RA) respectively against bacteria and Candida albicans. $p$-Iodonitrotetrazolium chloride (INT, Sigma-Aldrich) was used as microbial growth indicator.

\section{MIC and MMC determinations}

The MIC determinations on bacteria and C. albicans were conducted using rapid XTT colorimetric assay according to described methods $[24,25]$ with some modifications. Briefly, the test sample was first of all dissolved in $10 \%$ $(\mathrm{v} / \mathrm{v}) \mathrm{DMSO} / \mathrm{MHB}$ to give a final concentration of $512 \mu \mathrm{g} /$ $\mathrm{ml}$ and serially diluted twofold to obtain the concentration ranges $(4-512 \mu \mathrm{g} / \mathrm{ml}$ for the crude extract, fractions and isolated compounds, and 1-128 $\mu \mathrm{g} / \mathrm{ml}$ for chloramphenicol and nystatin used as RA). $100 \mu \mathrm{l}$ of each concentration was added in a well (96-well microplate) containing $95 \mu \mathrm{l}$ of MHB and $5 \mu \mathrm{l}$ of inoculum (standardized at $1.5 \times 10^{6}$ $\mathrm{CFU} / \mathrm{ml}$ by adjusting the optical density to 0.1 at $600 \mathrm{~nm}$ SHIMADZU UV-120-01 spectrophotometer) [26]. The final concentration of DMSO in the well was less than 3\% (preliminary analyses with 3\% (v/v) DMSO do not alter the growth of the test organisms). The negative control well consisted of $195 \mu \mathrm{l}$ of MHB and $5 \mu$ of the standard inoculum [27]. The plates were covered with a sterile plate sealer, then agitated to mix the contents of the wells using a plate shaker and incubated at $37^{\circ} \mathrm{C}$ for $24 \mathrm{~h}$. The assay was repeated three times. The MIC of samples was detected following addition $(40 \mu \mathrm{l})$ of $0.2 \mathrm{mg} / \mathrm{ml} p$ iodonitrotetrazolium chloride and incubation at $37^{\circ} \mathrm{C}$ for 30 min [24,25]. Viable microorganisms reduced the yellow dye to a pink colour. MIC was defined as the lowest sample concentration that prevented this change and exhibited complete inhibition of bacterial growth. For the determination of MMC, a portion of liquid $(5 \mu \mathrm{l})$ from each well that showed no change in colour was plated on MHA and incubated at $37^{\circ} \mathrm{C}$ for $24 \mathrm{~h}$. The lowest concentration that yielded no growth after this sub-culturing was taken as the MMC [8].

\section{Results and discussion}

The chemical structures of the isolated compounds were established using spectroscopic analysis, especially, NMR spectra in conjunction with $2 \mathrm{D}$ experiments, COSY, $\mathrm{HMQC}, \mathrm{HMBC}$, and direct comparison with published information and with authentic specimens obtained by our research group for some cases. The compounds isolated from the roots of $F$. polita (Figure 1) were identified as euphol-3-O-cinnamate $\mathrm{C}_{39} \mathrm{H}_{56} \mathrm{O}_{2}(1 ; 14 \mathrm{mg} ; \mathrm{Mw}$ : 556; m.p. $\left.110-111^{\circ} \mathrm{C}\right)$ [18], lupeol $\mathrm{C}_{30} \mathrm{H}_{50} \mathrm{O}(2 ; 44 \mathrm{mg} ; \mathrm{Mw}$ : 426; m.p. 215-216 $\left.{ }^{\circ} \mathrm{C}\right)$ [19], taraxar-14-ene $\mathrm{C}_{30} \mathrm{H}_{50} \mathrm{O}_{1}(3 ; 13$ mg; Mw: 426; m.p. 211-213 ${ }^{\circ} \mathrm{C}$ ) [20], ursolic acid $\mathrm{C}_{30} \mathrm{H}_{50} \mathrm{O}_{3}$ (4; 18 mg; $\mathrm{Mw}: 456 ;$ m.p. $284-285^{\circ} \mathrm{C}$ ) [21], $\beta$-sitosterol $\mathrm{C}_{29} \mathrm{H}_{50} \mathrm{O}$ (5; $220 \mathrm{mg} ; \mathrm{Mw}: 414 ;$ m.p. 277-278 ${ }^{\circ} \mathrm{C}$ ) [22], betulinic acid $\mathrm{C}_{30} \mathrm{H}_{48} \mathrm{O}_{3}(6 ; 16 \mathrm{mg} ; \mathrm{Mw}: 456 ;$ m.p. $295-$ $297^{\circ} \mathrm{C}$ ) [23], sitosterol 3-O- $\beta$ - $D$-glucopyranoside $\mathrm{C}_{35} \mathrm{H}_{60} \mathrm{O}_{6}$ (7; $25 \mathrm{mg}$; Mw: 576; amorphous powder) [22] and (E)-3,5,4'-trihydroxy-stilbene-3,5-O- $\beta$ - $D$-diglucopyranoside $\mathrm{C}_{26} \mathrm{H}_{32} \mathrm{O}_{13}$ (8; $30 \mathrm{mg} ; \mathrm{Mw}$ : 576; amorphous powder) [22]. However, the isolation of compounds 2, 4, 6 and 7 from this plant was reported [14]. Using previously described protocol [14] for the purification of F. polita, four additional known compounds $(\mathbf{1}, \mathbf{3}, \mathbf{5}$ and $\mathbf{8})$ were isolated from the roots extract. The isolated compounds included non polar terpenoids as well as polar compounds such (E)-3,5,4'-trihydroxy-stilbene-3,5-O- $\beta$ - $D$-diglucopyranoside, justifying the use of methanol as a good extraction solvent of bioactive metabolites from medicinal plants. This extract, fractions as well as compounds $\mathbf{1}$ and $\mathbf{8}$ were tested for their antibacterial activities and against C. albicans. The results are reported in Tables 1 and 2 .

The MIC results summarized in Table 1 , showed that the crude extract, fractions FPR1, FPR2 and compound $\mathbf{8}$ were able to prevent the growth of all the eight tested microorganisms. Other samples showed selective activity. The lowest MIC value of $64 \mu \mathrm{g} / \mathrm{ml}$ for the crude extract was recorded on four of eight (50\%) studied microbial species. The corresponding value for fractions $(32 \mu \mathrm{g} / \mathrm{ml})$ was obtained on Salmonella typhi, Escherichia coli and Candida albicans ATCC strains. Such activity can be considered as important, when considering the threshold MIC value $(100 \mu \mathrm{g} / \mathrm{ml})$ for plant extracts with significant activity [28]. Nonetheless, the corresponding cutoff point for compounds $(10 \mu \mathrm{g} / \mathrm{ml})$, is not acheived with the tested compounds. However compound $\mathbf{8}$ exhibited moderate activities [28], the MICs below $100 \mu \mathrm{g} / \mathrm{ml}$ being recorded on three of the eight microorganisms tested. Taking in account the fact that F. polita is and edible plant, its seems reasonable to consider a more flexible stringent criteria indicating that extracts with MIC values below $8 \mathrm{mg} / \mathrm{ml}$ [29] are considered to possess some antimicrobial activity and natural products with MIC values below $1 \mathrm{mg} / \mathrm{ml}$ are considered 
Table $1 \mathrm{MIC}(\mu \mathrm{g} / \mathrm{ml})$ of the crude extract, fractions and compounds isolated from the roots of $F$. polita and reference antibiotics on the studied microbial species

\begin{tabular}{|c|c|c|c|c|c|c|c|c|}
\hline \multirow[t]{3}{*}{ Tested samples $^{a}$} & \multicolumn{8}{|c|}{ Microorganisms, strains and MIC $(\mu \mathrm{g} / \mathrm{ml})^{\mathrm{b}}$} \\
\hline & \multirow{2}{*}{$\begin{array}{c}\text { P. smartii } \\
\text { ATCC29916 }\end{array}$} & \multirow{2}{*}{$\begin{array}{c}\text { P. aeruginosa } \\
\text { PA01 }\end{array}$} & \multirow{2}{*}{$\begin{array}{c}\text { K. pneumoniae } \\
\text { ATCC11296 }\end{array}$} & \multirow{2}{*}{$\begin{array}{c}\text { S. aureus } \\
\text { ATCC25922 }\end{array}$} & \multirow{2}{*}{$\begin{array}{c}\text { S. typhi } \\
\text { ATCC6539 }\end{array}$} & \multicolumn{2}{|c|}{ E. coli } & \multirow{2}{*}{$\begin{array}{l}\text { C. albicans } \\
\text { ATCC } 9002\end{array}$} \\
\hline & & & & & & ATCC8739 & AG100 & \\
\hline FPR & 128 & 128 & 128 & 64 & 64 & 64 & 256 & 64 \\
\hline FPR1 & 64 & 64 & 128 & 64 & 32 & 32 & 128 & 32 \\
\hline FPR2 & 256 & 128 & 256 & 256 & 256 & 128 & 256 & 64 \\
\hline FPR3 & - & - & - & - & - & 512 & - & - \\
\hline FPR4 & 512 & - & 512 & - & - & 512 & - & - \\
\hline FPR5 & 256 & 256 & 512 & 128 & 256 & 256 & - & 128 \\
\hline 1 & - & 512 & - & 512 & 512 & 256 & - & 512 \\
\hline 8 & 256 & 64 & 128 & 64 & 64 & 64 & 256 & 128 \\
\hline RA & 32 & 64 & 4 & 4 & 4 & 4 & 4 & 16 \\
\hline
\end{tabular}

${ }^{a}$ The tested samples were compounds 1: euphol 3-O-cinnamate; 8: (E)-4'-hydroxystilbene-3,5-O- $\beta$-diglucopyranoside and chloramphenicol (for bacteria) and nystatin (for C. albicans) used as the reference antibiotics (RA); the crude extract (FPR) and fractions (FPR1 to 5) from F. polita roots;

${ }^{\mathrm{b}}$ The tested microorganisms were Providencia smartii (P. smartii); Pseudomonas aeruginosa (P. aeruginosa); Klebsiella neumonia (K. pneumonia); Staphylococcus aureus (S. aureus); Salmonella typhi (S. typhi); Escherichia coli (E. coli); Candida albicans (C. albicans). (-): MIC > $512 \mu \mathrm{g} / \mathrm{ml}$.

noteworthy [30,31]. Therefore, the activity recorded therefore with the extract, some of the fractions and compounds $\mathbf{8}$ could be considered as important, highlighting the antimicrobial potency of $F$. polita. The MIC values recorded with compound $\mathbf{8}$ on the resistant $P$. aeruginosa PA01 was equal to that of chloramphenicol used as reference antibiotic, confirming this hypothesis. The results of Table 2 showed detectable MMC values for some of the studied samples on the tested microbial strains. When analysing carefully the MIC and MMC results for the crude extract, fractions FPR1 and 2, compounds $\mathbf{8}$, it can be noted that MMC/MIC ratios lower than 4 were obtained with most of the studied samples, suggesting that killing effects could be expected [32]. To the best of our knowledge, the activity of this plant, compounds $\mathbf{1}$ and $\mathbf{8}$ on the microorganisms studied in the present work is being reported for the first time. Compounds with enough evidence of their antimicrobial microbial activities such lupeol [33], betulinic acid [34], ursolic acid [35], $\beta$-sitosterol, sitosterol-3-O- $\beta$ - $D$-glucopyranoside [36,37], were not tested again in the present work. However, compounds such as lupeol exhibited moderate inhibitory effect against E. coli and Mycobacterium smegmatis [33]. Nonetheless, these terpenoid-like compounds mostly exhibited poor or moderate activities. Their presence as well as that of Euphol 3-O-cinnamate and (E)-4'-hydroxystilbene-3,5-O- $\beta$-diglucopyranoside, and possible synergistic activities, can explain the good antimicrobial activity observed with the crude extract of F. polita and fractions. Finally, the overall activities of

Table $2 \mathrm{MMC}(\mu \mathrm{g} / \mathrm{ml})$ of the crude extract, fractions and compounds isolated from the roots of $F$. polita and reference antibiotics on the studied microbial species

\begin{tabular}{|c|c|c|c|c|c|c|c|c|}
\hline \multirow[t]{3}{*}{ Tested samples $^{a}$} & \multicolumn{8}{|c|}{ Microorganisms, strains and MIC $(\mu \mathrm{g} / \mathrm{ml})^{b}$} \\
\hline & \multirow{2}{*}{$\begin{array}{c}\text { P. smartii } \\
\text { ATCC29916 }\end{array}$} & \multirow{2}{*}{$\begin{array}{c}\text { P. aeruginosa } \\
\text { PA01 }\end{array}$} & \multirow{2}{*}{$\begin{array}{c}\text { K. pneumoniae } \\
\text { ATCC11296 }\end{array}$} & \multirow{2}{*}{$\begin{array}{c}\text { S. aureus } \\
\text { ATCC25922 }\end{array}$} & \multirow{2}{*}{$\begin{array}{c}\text { S. typhi } \\
\text { ATCC6539 }\end{array}$} & \multicolumn{2}{|c|}{ E. coli } & \multirow{2}{*}{$\begin{array}{l}\text { C. albicans } \\
\text { ATCC } 9002\end{array}$} \\
\hline & & & & & & ATCC8739 & AG100 & \\
\hline FPR & 256 & 256 & 256 & 128 & 256 & 128 & 512 & 128 \\
\hline FPR1 & 128 & 128 & 256 & 128 & 64 & 64 & 128 & 64 \\
\hline FPR2 & 512 & 512 & 512 & 512 & 512 & 256 & 512 & 256 \\
\hline FPR3 & nd & - & - & - & - & $>512$ & nd & nd \\
\hline FPR4 & $>512$ & - & $>512$ & - & - & $>512$ & nd & nd \\
\hline FPR5 & 512 & 512 & $>512$ & 128 & 512 & 512 & nd & 128 \\
\hline 1 & nd & $>512$ & nd & $>512$ & $>512$ & $>512$ & nd & $>512$ \\
\hline 8 & 512 & 256 & 256 & 128 & 128 & 128 & 512 & 256 \\
\hline RA & 64 & 128 & 8 & 8 & 8 & 8 & 8 & 32 \\
\hline
\end{tabular}

${ }^{a}$ The tested samples were compounds 1: euphol 3-O-cinnamate; 8: (E)-4'-hydroxystilbene-3,5-O- $\beta$-diglucopyranoside and chloramphenicol (for bacteria) and nystatin (for C. albicans) used as the reference antibiotics (RA); the crude extract (FPR) and fractions (FPR1 to 5) from F. polita roots;

${ }^{b}$ The tested microorganisms were Providencia smartii (P. smartii); Pseudomonas aeruginosa (P. aeruginosa); Klebsiella pneumoniae (K. pneumoniae); Staphylococcus aureus (S. aureus); Salmonella typhi (S. typhi); Escherichia coli (E. coli); Candida albicans (C. albicans). (-): not determined because MIC value was not detected up to $512 \mu \mathrm{g} / \mathrm{ml}$; (nd): not determined; >512: value above $512 \mu \mathrm{g} / \mathrm{ml}$. 
this plant might be due to the presence of several antimicrobial compounds with moderate activities.

\section{Conclusion}

The results of this study provide informative data for the use of the crude extract from Ficus polita against bacterial microbial infections.

\section{Acknowledgements}

Authors are thankful to the Cameroon National Herbarium (Yaounde) for the plant identification.

\section{Author details}

'Department of Biochemistry, Faculty of Science, University of Dschang, Cameroon. ${ }^{2}$ Department of Organic Chemistry, Faculty of Science, University of Yaoundé I, Cameroon. ${ }^{3}$ Department of Pharmacy and Traditional Pharmacopoeia, Faculty of Medicine and Biomedical Science, University of Yaoundé I, Cameroon.

\section{Authors' contributions}

VK and JK carried out the study and wrote the manuscript; LPS, BN and PA participate to structural elucidation of compounds. BTN supervised the work and the manuscript writting. All authors read and approved the final manuscript.

\section{Competing interests}

The authors declare that they have no competing interests.

Received: 24 November 2010 Accepted: 26 January 2011 Published: 26 January 2011

\section{References}

1. World Health Organisation: WHO Guideline for the Assessment of herbal medicines. WHO Expert Committee on specification for pharmaceutical preparation. Technical Report series no. 863 Geneva; 1996.

2. Zaika LL: Spices and herbs: their antimicrobial activity and its determination. J Food Safety 1975, 9:97-118.

3. Gordon MC, David JN: Natural product drug discovery in the next millennium. Pharmaceut Biol 2001, 139:8-17.

4. Cordell GA: Newroots for an old science. In Studies in Natural Products Chemistry. Pharmacognosy 13: Bioactive Natural Products (Part A). Edited by: Atta-ur-Rahman Basha FZ. Elsevier, Amsterdam; 1993.

5. Mbaveng AT, Ngameni B, Kuete V, Konga Simo I, Ambassa T, Roy R, Bezabih M, Etoa FX, Ngadjui BT, Abegaz BM, Meyer JJM, Lall N, Penlap BV: Antimicrobial activity of the crude extracts and five flavonoids from the twigs of Dorstenia barteri (Moraceae). J Ethnopharmacol 2008, 116:483-489.

6. Ngameni B, Kuete V, Konga Simo I, Mbaveng AT, Awoussong PK, Patnam R, Roy $R$, Ngadjui BT: Antibacterial and antifungal activities of the crude extract and compounds from Dorstenia turbinata (Moraceae). 5 Afr J Bot 2009, 75:256-261.

7. Kuete V, Metuno R, Ngameni B, Tsafack AM, Ngandeu F, Fotso GW, Bezabih M, Etoa FX, Ngadjui BT, Abegaz BM, Beng VP: Antimicrobial activity of the methanolic extracts and compounds from Treculia africana and Treculia acuminata (Moraceae). S Afr J Bot 2008, 74:111-115.

8. Kuete V, Ngameni B, Fotso Simo CC, Kengap Tankeu R, Tchaleu Ngadjui B, Meyer JJM, Lall N, Kuiate JR: Antimicrobial activity of the crude extracts and compounds from Ficus chlamydocarpa and Ficus cordata (Moraceae). J Ethnopharmacol 2008, 120:17-24.

9. Kuete V, Nana F, Ngameni B, Mbaveng AT, Keumedjio F, Ngadjui BT: Antimicrobial activity of the crude extract, fractions and compounds from stem bark of Ficus ovata (Moraceae). J Ethnopharmacol 2009, 124:556-561.

10. Kuete V, Fozing DC, Kapche WFGD, Mbaveng AT, Kuiate JR, Ngadjui BT, Abegaz BM: Antimicrobial activity of the methanolic extract and compounds from Morus mesozygia stem bark. J Ethnopharmacol 2009, 124:551-555.

11. Kuete V, Ngameni B, Mbaveng AT, Ngadjui B, Marion Meyer JJ, Lall N: Evaluation of flavonoids from Dorstenia barteri for their antimycobacterial, antigonorrheal and anti-reverse transcriptase activities. Acta Trop 2010, 116:100-104.
12. Berhaut J: [Flore Illustrée du Sénégal: Dicotylédones, Tome IV]. Dakar, Direction des Eaux et Forêts; 1979.

13. Etkin NL, Ross PJ: Food as medicine and medicine as food: An adaptive framework for the interpretation of plant utilization among the Hausa of northern Nigeria. Soc Sci Med 1982, 16:1559-1573.

14. Kamga J, Sandjo LP, Poumale HMP, Ngameni B, Shiono Y, Yemloul M, Rincheval V, Ngadjui BT, Kirsch G: Politamide, a new constituent from the stem bark of Ficus polita Vahl (Moraceae). Arkivoc 2010, ii:323-329.

15. Recio MC, Giner RM, Maiiez S, Rios JL, Marston A, Hostettmann K: Screening of Tropical Medicinal Plants for Antiinflammatory Activity. Phytother Res 1995, 9:571-574.

16. Ayisi NK, Nyadedzor C: Comparative in vitro effects of AZT and extracts of Ocimum gratissimum, Ficus polita, Clausena anisata, Alchornea cordifolia, and Elaeophorbia drupifera against HIV-1 and HIV-2 infections. Antivir Res 2003, 58:25-33.

17. Gbeassor M, Kedjagni AY, Koumaglo K, de Soma C, Agbo K, Aklikokou K, Amegbo KA: In Vitro Antimalarial Activity of Six Medicinal Plants. Phytother Res 1990, 4:115-117.

18. Gewali MB, Hattori M, Tezuka Y, Kikuchi T, Namba T: Constituents of the latex of Euphorbia antiquorum. Phytochemistry 1990, 29:1625-1628.

19. Chian YM, Ku Y: Novel triterpenoids from the aerial roots of Ficus microcarpa. J Org Chem 2002, 67:7656-7661.

20. Kuo YH, Chaiang YY: Five new taraxastane-type triterpenes from the aerial roots of Ficus microcarpa. Chem Pharm Bull 1999, 47:498-500.

21. Seebacher W, Simic N, Weis R, Saf R, Kunert O: Complete assignments of $1 \mathrm{H}$ and $13 \mathrm{C}$ NMR resonances of oleanolic acid, 18a-oleanolic acid, ursolic acid and their 11-oxo derivatives. Magn Reson Chem 2003, 41:636-638.

22. Xu ML, Zheng MS, Lee YK, Moon DC, Lee CS, Woo MH, Jeong BS, Lee ES, Jahng Y, Chang HW, Lee SH, Son JK: A new stilbene glucoside from the roots of Polygonum multiflorum Thunb. Arch Pharm Res 2006, 29:946-951.

23. Simo CCF, Kouam SF, Poumale HMP, Simo IK, Ngadjui BT, Green IR, Krohn K: Benjaminamide: A new ceramide and other compounds from the twigs of Ficus benjamina (Moraceae). Biochem Syst Ecol 2008, 36:238-243.

24. Eloff JN: A sensitive and quick microplate method to determine the minimal inhibitory concentration of plant extracts for bacteria. Planta Med 1998, 64:711-713.

25. Pettit RK, Weber CA, Kean MJ, Hoffmann H, Pettit GR, Tan R, Franks KS, Horton ML: Microplate alamar blue assay for Staphylococcus epidermidis biofilm susceptibility testing. Antimicrob Agent Chemother 2005, 49:2612-2617.

26. Tereschuk ML, Riera MVQ, Castro GR, Abdala LR: Antimicrobial activity of flavonoid from leaves of Tagetes minuta. J Ethnopharmacol 1997, 56:227-232.

27. Zgoda JR, Porter JR: A convenient microdilution method screening natural products against bacteria and fungi. Pharmaceut Biol 2001, 39:221-225.

28. Kuete V: Potential of Cameroonian plants and derived-products against microbial infections: A review. Planta Med 2010, 76:1-13.

29. Fabry W, Okemo PO, Ansorg R: Antibacterial activity of East African medicinal plants. J Ethnopharmacol 1998, 60:79-84.

30. Gibbons S: Anti-staphylococcal plant natural products. Nat Prod Rep 2004, 21:263-277.

31. Rios JL, Recio MC: Medicinal plants and antimicrobial activity. J Ethnopharmacol 2005, 100:80-84.

32. Carbonnelle B, Denis F, Marmonier A, Pinon G, Vague R: Bactériologie médicale: Techniques usuelles. SIMEP, Paris; 1987.

33. Kuete V, Wansi JD, Mbaveng AT, Kana Sop MM, Tadjong AT, Beng VP, Etoa FX, Wandji J, Meyer JJM, Lall N: Antimicrobial activity of the methanolic extract and compounds from Teclea afzelii (Rutaceae). S Afr J Bot 2008, 74:572-576

34. Mbaveng AT, Kuete V, Nguemeving JR, Krohn K, Nkengfack AE, Meyer JJM, Lall N: Antimicrobial activity of the extracts and compounds from Vismia guineensis (Guttiferae). Asian Journal of Traditional Medicine 2008, 3:211-223.

35. Collins MA, Charles HP: Antimicrobial activity of Carnosol and Ursolic acid: two anti-oxidant constituents of Rosmarinus officinalis L. Food Microbiol 1987, 4:311-315.

36. Kuete V, Eyong KO, Beng VP, Folefoc GN, Hussain H, Krohn K, Nkengfack AE, Saeftel M, Sarite SR, Hoerauf A: Antimicrobial activity of the methanolic extract and compounds isolated from the stem bark of Newbouldia laevis Seem. (Bignoniaceae). Pharmazie 2007, 62:552-556. 
37. Manríquez-Torres J, Zúñiga-Estrada A, González-Ledesma M, TorresValencia JM: The Antibacterial Metabolites and Proacacipetalin from Acacia cochliacantha. J Mex Chem Soc 2007, 51:228-231.

\section{Pre-publication history}

The pre-publication history for this paper can be accessed here:

http://www.biomedcentral.com/1472-6882/11/6/prepub

doi:10.1186/1472-6882-11-6

Cite this article as: Kuete et al: Antimicrobial activities of the methanol extract, fractions and compounds from Ficus polita Vahl. (Moraceae). BMC Complementary and Alternative Medicine 2011 11:6.

Submit your next manuscript to BioMed Central and take full advantage of:

- Convenient online submission

- Thorough peer review

- No space constraints or color figure charges

- Immediate publication on acceptance

- Inclusion in PubMed, CAS, Scopus and Google Scholar

- Research which is freely available for redistribution

Submit your manuscript at www.biomedcentral.com/submit
() BioMed Central 